\title{
ГЕНДЕРНИЙ АСПЕКТ КОМУНІКАТИВНОЇ ПОВЕДІНКИ ЛЮДИНИ : ПАРАМЕТРИ ВЕРБАЛЬНОЇ І НЕВЕРБАЛЬНОЇ КОМУНІКАЦІї
}

Осіпова Т. Ф. Гендерний аспект комунікативної поведінки людини: параметри вербальної і невербальної комунікації.

У статті висвітлено фізіологічні й соціокультурні передумови гендерної комунікації, що реалізується вербальними й невербальними засобами, формуючи гендерні стереотипи комунікативної поведінки, знання яких є важливим чинником ефективної комунікації.

Ключові слова: комунікативна поведінка, параметри вербальної і невербальної комунікації, гендерна комунікація, гендерні стереотипи, ефективність комунікації.

Осипова Т.Ф. Гендерный аспект коммуникативного поведения человека: параметры вербальной и невербальной коммуникации.

В статье описаны физиологические и социокультурные основы гендерной коммуникации, которые реализуются с помощью вербальных и невербальных средств, формируя гендерные стереотипы коммуникативного поведения, знание которых обеспечивает эффективность коммуникации.

Ключевые слова: коммуникативное поведение, параметры вербальной и невербальной коммуникации, гендерная коммуникация, гендерные стереотипы, эффективность коммуникации.

Osypova T. F. Gender aspect of communicative behaviour of a human: verbal and non-verbal parameters of communication.

Physiological and sociocultural preconditions for gender communication which realizes both by verbal and non-verbal means and forms gender stereotypes of communicative behaviour were analyzed in the article. The knowledge of such stereotypes is an important factor in efficient communication.

Key words: communicative behavior, verbal and non-verbal communication parameters, gender communication, gender stereotypes, communication efficiency.

Специфіка комунікації чоловіка й жінки між собою й з іншими має глибоке соціофізіологічне підгрунтя, що пов' язане з еволюцією людини. Як зазначають фахівці, доісторична людина мала обмежене коло спілкування - за все життя вона могла зустрітися приблизно зі 150 особами, що відповідно впливало на рівень вербального спілкування; до того ж, відповідну роль відігравала й особлива диференційована діяльність давнього чоловіка й жінки - чоловіка як мисливця, змушеного більше мовчати, логічно мислити й орієнтуватися в просторі та жінки як домашньої господині й виховательки дітей, що потребувало відповідної 
вербальної активності [1]. Звідси й специфіка сприйняття в комунікації: чоловіче - переважно лівою півкулею головного мозку, що відповідає за аналітичне мислення людини і його вербальне втілення, жіноче - як лівою, так і правою півкулею, що відповідає за обробку інформації, яка виражена в символах й образах, а не в словах [1].

Фахівці відзначають також відмінність у гендерному сприйнятті мовлення. Для чоловіків важливо те, щцо говорять, а для жінок переважно те, як говорять; чоловіків уважають емоційними внаслідок превалювання в них у крові тестостерону - гормону бажання й агресії, а жінок - чуттєвими, оскільки їхня кров більш насичена естрогенами, що сприяють активізації захисних та пристосувальних реакцій [1].

Фізіологи зазначають, що чоловік і жінка різняться між собою як види. $€$ твердження, що людина й мавпа мають однакову генетичну спадковість - 98,4\% , зокрема чоловіка або жінку від самця або самиці мавпи віддаляють лише 1,6 \% цієї спадковості. Натомість чоловіка й жінку різнять 5\% геному людини, отже, цей постулат дає змогу вченим стверджувати, що чоловік або жінка є природно ближчими до своїх видових пращурів, аніж один до одного в межах одного виду [1].

Гендер виявляється на різних соціально обумовлених рівнях, але загалом формує комунікативну поведінку індивідууму. «Під комунікативною поведінкою розуміємо сукупність норм і традицій спілкування народу, вікової, професійної та ін. групи» [15, с. 106]. Виявити гендерні ознаки комунікативної поведінки можливо, як стверджують фахівці, лише шляхом іiі детального опису за певними комунікативними характеристиками, насамперед виявом здатності до реалізації ймовірних контактів, комунікативної привітності, товариськості, комунікативної емоційності, здатності до підтримки комунікативного контакту, виявом характеру виходу з комунікативного контакту, комунікативним демократизмом, комунікативною самопрезентацією, етикою спілкування, комунікативним тиском, комунікативним контролем, тематичною зумовленістю спілкування, дискусійністю, вибором кола спілкування й типу співбесідника, орієнтацією на співбесідника, фізичним контактом, співвідношенням вербального й невербального спілкування, жестикуляцією, мімікою, гучністю, темпом спілкування тощо [15, с. 106].

Комунікативна поведінка, як відомо, визначається певною гнучкістю й динамікою відповідно до ситуації або традиції; вона формує відповідні динамічні моделі - комунікативні стереотипи (в аспекті гендеру - гендерні), що зафіксовані мовою, в мовленнєвій 
поведінці індивідів, що визнають себе особами певної статі. «Під гендерними стереотипами розуміють стандартне судження про якість, атрибути та норми поведінки представників обох статей відповідної соціальної групи або окремих осіб певної групи» [13, с. 102]. Для характеристики гендерних стереотипів дослідники пропонують i такий метафоричний термін, як «комунікативний портрет суб'єкта» [17, с. 124], що об'єднує в певну систему ознаки гендерної стереотиповості на відповідному синхронічному зрізі, оскільки останні перебувають в постійній діахронічній динаміці відповідно до розвитку суспільства, а саме: когнітивний стан (концептуальні властивості суб' єкта), вербально-семантична компетентність (мовна / мовленнєва поведінка суб'єкта), мотиваційно-прагматичний чинник (комунікативні установки суб' єкта (Ю. Караулов), моторно-артикуляційні можсливості (жести, міміка, рухи), національний менталітет, емоційний стан (Л. Каменская). Цю модель пропонують як концептуальну для виявлення гендерних стереотипів або створення комунікативного портрета суб' єкта [17, с. 123-124].

Отже, зазначені параметри характеризують комунікативну поведінку чоловіка й жінки як у межах власне статі, так i на контрастивному тлі. Спроба укрупнення деяких із них покриває певні лакуни в теорії і практиці комунікації.

Спостереження за комунікативною поведінкою чоловіків і жінок у моногамних і гетерогамних групах надали можливість визначити деякі найбільш стереотипізовані гендерні стратегії й тактики, що залежать від різних типів інтерпретації світу й відображають гендерні особливості в комунікативних процесах $[9$, с. 22].

Уважається, що жінки в комунікації дотримуються переважно стилю співробітництва, чоловіки - конкуренції, відповідно вони використовують специфічні комунікативні тактики: жінки, як правило, дотримуються теми розмови, почерговості мовлення, чоловіки тяжіють до тактик самоствердження, встановлення домінування. Головною ж відмінністю вважають ставлення до зворотного зв'язку: існує думка, що жінка сприймає зворотне повідомлення не стільки як реакцію на повідомлення як таке, скільки як знак взаєморозуміння; чоловіки ж сприймають його як інформацію, що може не збігатися 3 їх розумінням, і тому як таке, що підлягає сумніву, а інколи - як помилкове [11, с. 26].

Розрізняють відповідно й стилі мовлення чоловіка й жінки: мовлення чоловіка зазвичай пряме, тверде, дещо грубе, різке, 
вимогливе, прямолінійне, жінки - спокійне, м'яке, довірливе, мирне, дещо цнотливе, іноді наївне. Зазначають також, що чоловіки надають перевагу спілкуванню в групі, що сприяє реалізації можливостей до самопрезентації, натомість жінки тяжіють до спілкування в парах, міжособистісного спілкування [14, с. 32].

Узаємодіючи в гетерогамних групах, жінки й чоловіки використовують різноспрямовані комунікативні стратегії, внаслідок чого виникає чимало непорозумінь, інколи таких, що спричиняють комунікативні девіації. Від представників сильної статі можна почути: «жінка $\epsilon$ жінка», «мовчи, жінко», що ілюструє певне ставлення до жіноцтва в комунікації, визначення комунікативної ролі жінки. Натомість жінки сприймають чоловіків із неменшою критикою або навіть іронією, зокрема в «жіночому» мовленні поширені такі вислови: «поводиться як мужик (мужлан)» (розм.), «..як баба».

Гендерна стереотипізація, як відомо, фіксується в мові на всіх рівнях і тісно пов' язана 3 формами вираження оцінки [2]. Цікавими й продуктивними $є$ наукові розвідки, присвячені вивченню вербалізації оцінки в мовленні чоловіків і жінок у прямій і особливо в непрямій комунікації. Зважаючи на певну гендерну полярність, і чоловіки, і жінки схильні до ущипливості стосовно один до одного, яка реалізується переважно в непрямих комунікативних актах - у формі прецедентних текстів: прислів'їв або приказок, загальновідомих висловів із художньої літератури, рядків із пісні, репліки з кінофільму тощо; ущипливий вислів може бути поданий як антифразис (завдяки відповідній інтонації), як порівняння 3 літературними, історичними постатями, фактами (алюзіі) [5, с.62]. Помічено також, що жінки є більш винахідливими в ущипливості - вони подають ущипливий вислів як непрямо висловлену пораду, похвалу або комплімент. Чоловіки ж «маскують» ущипливість у вигляді анекдоту, армійського гумору або ж використовують пряме висловлення у формі знущання або образи [5, с. 63]. Натомість проводити чітку межу між тактиками чоловіків і жінок уважаємо неприйнятним, оскільки їх дії залежать не тільки від індивідуально-психічних особливостей кожної людини, але й від комунікативної ситуації, в умовах якої розгортається гендерний дискурс.

Отже, оцінці в гендерній комунікації належить панівна роль, i головним критерієм оцінювання комунікативної поведінки $є$ саме стереотипізовані уявлення про комунікативні ролі чоловіка й жінки у спілкуванні, що створені певним етносом або соціальною групою. Збіг або змішування різних соціальних і комунікативних гендерних ролей 
уважають загрозою віковим суспільним установкам, чинниками руйнування жорсткої ієрархічної моделі або відхиленням від норми [7, с. 68].

Вивчення «культурних домінант, що становить систему дослідницьких процедур, спрямованих на висвітлення різноманітних кіл концептів певної культури» $є$ найбільш продуктивною гендерною методикою [3]. Гендер - це невід'ємний компонент мовленнєвої поведінки у вигляді кодів, він зумовлює тематику й характер мовленнєвих актів, підтверджуючись мовними засобами, що дають змогу людині самопрезентуватись у соціумі як чоловік або жінка [8, с. 18].

Особливо актуальними є ці знання в сучасному міжкультурному просторі, що мотивовані світовими процесами глобалізації. При цьому «важливо встановити місце гендерного концепту в цілісний картині світу, а також з'ясувати специфіку віддзеркалення в мові стереотипів, пов'язаних зі статтю» [3]. Але, як свідчить досвід міжкультурної комунікації, суспільні процеси неспроможні подолати вікові традиції, що різною мірою виявляються в комунікації на певних іiі етапах. «Сучасне життя змінило рольові ознаки статі та взаємостосунки між ними» [6, с. 68]; процеси розвитку суспільства надали можливість жінкам більш активно виявляти себе, що призвело останнім часом навіть до зміни комунікативних ролей. Зокрема жінка-керівник, «бізнесвумен», жінка-військовослужбовець, жінка-водій тощо повинні дотримуватись чоловічого стилю в комунікації, інакше вони не зможуть досягнути успіху в обраній ролі. При цьому оцінка жіночої комунікативної поведінки експонується 3 позицій чоловічого світогляду. Наприклад, образ жінки-судді містить такі оцінні характеристики, як непередбачуваність («Суддя відмовилась задовольнити вимоги адвоката без будь-яких формулювань»), емоційність («Увесь зал витирає сльози, суддя ледве стримується»), схильність до співчуття («Суддя намагалася заспокоїти жінку, але важко добирала слова»), категоричність, що межує з упертістю («Ми півгодини умовляли суддю перенести обговорення хоч би на завтра») (з газетних шпальт) [13, с. 103]. Натомість опанування чоловіками споконвічно «жіночих» ролей не супроводжується зміною комунікативних стилів, навпаки, нові соціальні ролі чоловіки виконують по-своєму особливо, що надає їм певної привабливості й сприяє успішній комунікативній діяльності. Чоловіки-кухарі, чоловікивихователі, чоловіки-стилісти й дизайнери, чоловіки-повивальники вже давно й справедливо вважаються кращими за жінок у цих ролях саме 
завдяки тому, що зберігають свій «чоловічий» стиль. При цьому, звісно, варто враховувати певні відхилення в поведінці окремих чоловіків, що наслідують манери жінок, їх зовнішність або стиль спілкування.

Учені зауважують, що сьогодні простежуємо значне послаблення поляризації гендерних ролей, взаємопроникнення жіночих та чоловічих компонентів, нівелювання відмінностей у складі гендерних стереотипів [10, с. 25]. Сучасні науковці стверджують, що гендерні особливості виявляються ще на ранніх етапах розвитку людини - в процесі засвоєння рідної мови. Розрізняють два типи засвоєння мови референційний та експресивний. Перший визначається превалюванням такої мовної дії, як називання об'єктів, другий - регулювання власної діяльності та встановлення контакту з іншими [12, с. 100]. Відповідно до експериментальних висновків відзначають деякі особливості першого (референційного) типу, зокрема превалювання в мовленні розповідних речень, перевага говоріння над імітацією, швидкий темп росту словника, використання тільки слів, що мають смисл, зокрема високий відсоток у лексиконі іменників і прикметників, їх імітування, відсутність «заморожених», стандартизованих фраз, на ранніх стадіях довготривале використання незмінних слів та визначення себе як третьої особи. Другий (експресивний) тип характеризується превалюванням у мовленні спонукальних речень із яскравим імітувальним і клішованим наповненням, низьким відсотком використання іменників серед перших 50 слів, майже відсутністю прикметників у лексиконі, повільним темпом росту словника, натомість ранньою здатністю змінювати слова й використовувати займенник «я» на позначення власної особи. Помічено, що більш референційними є дівчатка, а більш експресивними хлопчики [12, с. 100]. Однак знову-таки можемо не погодитися 3 такими категоричними твердженнями, оскільки ці відомості цілком нівелюються параметром індивідуальності, обдарованості та унікальності кожної людини.

Гендерно маркованою уважають й таку ознаку, як якість мовлення, зокрема, характеризуючи мовлення чоловіка, використовують такі маркери: говорить твердо, грізно, з жаром, вирує, горланить. Характеристика жіночого мовлення вербалізована такими лексемами: виговорити, випалити, видавити, просити, передражнювати, бурчати, белькотати, говорити тремтячим голосом, зітхаючи, жалісним або слабким голосом, повільно й тихо, з розстановкою тощо. Вибір мовних формул на позначення адресата мовлення зумовлений насамперед психологічними особливостями чоловіка й жінки, які по-різному 
омовлюють світ відповідно до сприйняття, що реалізується так званим внутрішнім мовленням [16, с. 104].

Фахівці з комунікативного гендеру зазначають: «С почуття, що переживають тільки жінки або чоловіки; є смисли, які формуються у свідомості тільки жінки чи чоловіка, а отже, $\epsilon$ відповідний цим настановам вибір мовних засобів, природний для одних і неактуальний, необов'язковий для інших» [14, c. 30]. Аналіз художніх текстів 3 позицій його гендерного авторства ілюструє певні розбіжності мовлення чоловіка й жінки, зокрема в самозвертанні. Відзначають, що при цьому жінки обирають більш критичні формули, а чоловіки надають перевагу позитивно забарвленим звертанням, порівн.: Om щзо ти наробила, ідіотко! Ну от, дурепо, ти сама заварила ияю кашу! (Л. Баграт) - жіноче; E, шановний, уставай! Надворі вже геть споночіло.. Ну, Павлусю... пригадай, щзо ти - майстер спорту 3 боксу... (О. Винокуров) - чоловіче [16, с. 105].

Викликають зацікавлення й форма звертання до соціально набутих батьків - тестя й тещі, свекра й свекрухи, оскільки в цій комунікативній ситуації виявляється й власне Еgо мовця, і його комунікативні наміри, стратегії й тактики. Експериментально виявлено, що номінацію «тато» вживають $41 \%$ чоловіків і $48 \%$ жінок; «мамо» - $44 \%$ чоловіків і $57 \%$ жінок, при цьому констатовано, що чоловіки інколи навіть уникають номінації батьків, заміняючи нейтральним: «Чуєте?», що вмотивовано їхніми намірами зберігати свою соціально-ієрархічну роль, натомість жінки прагнуть скоротити дистанцію з адресатом, налагодити контакти [16, с. 110].

Відзначають гендерну специфіку внутрішнього мовлення й у формах звертання до пасивного адресата: чоловіки, як зауважено, використовують переважно згрубілі або креативно грубі форми, навіть деінде ненормативні, жінки ж тяжіють до традиційних лексем, що репрезентують їхні емоції, але при цьому значну роль відіграють насамперед ситуація мовлення, індивідуально-психічні особливості мовця [16].

Варто врахувати, як видається, й висновки психологів щодо екстравертності жінок, яка виявляється в їхній активності, товариськості, емпатичності (співчуття) та інтравертності чоловіків, які більш автономні, авторитарні, настійливі та інтелектуальні [16, с. 103].

Психологи стверджують, що для жінок характерна більша лексична продуктивність, що мотивується більш глибоким осмисленням та потребою соціальної репрезентації власного 
емоційного досвіду. На сьогодні вчені розробили спеціальні методики обстеження лексичної активності, що надають можливість виявити гендерні особливості вербальної рецепції чоловіків і жінок у певних психологічних і комунікативних ситуаціях (А. Залевська, Ю. Караулов). За наслідками експериментів зроблено такі висновки: жінки більш багатослівні у своїх переживаннях, а чоловіки - більш лаконічні, але водночас вони більш оригінальні або індивідуальні у вербалізації власних емоцій.

Невербальна комунікація на гендерному рівні, як виявляється, є продуктом більш соціальним, оскільки пов'язана зі стереотиповими уявленнями щодо комунікативної поведінки чоловіка або жінки. Століттями вироблені правила цієї поведінки формально розподіляють невербальні засоби комунікації на чоловічі й жіночі, що загалом ілюструють силу, рішучість, агресивність чоловіка або чуттєвість, толерантність, емоційність жінки. Факт використання невербальних засобів у комунікації тісно пов' язаний із етикетом, що приписував або забороняв певні їх прояви у спілкуванні.

Науку, що вивчає невербальні знаки, категорії та знакову поведінку, а також принципи і правила невербальної взаємодії, як відомо, номінують невербальною семіотикою [7, с. 14]. Розподіл невербальних знаків на власне чоловічі або жіночі є некоректним, оскільки в певних комунікативних контекстах вони можуть бути використані обома статями. Інша справа, - як уважає Г. Крейлдін, - це стилі невербального спілкування, що зумовлені численними чинниками позамовної дійсності, зокрема природними, соціальними й культурними [7, с. 15].

Важливим чинником успішної комунікації є паралінгвістичні параметри. Голос виконує насамперед диференціювальну функцію за його допомогою видається можливим розрізнити стать людини, але як інструмент мовлення голос не лише передає емоційний стан мовця, але і $є$ знаряддям його інтенцій, загалом характеризує мовця, репрезентує його статус, рівень, манеру мовлення тощо. Чоловічий голос, як правило, має низькі тональні характеристики, напр. говорити басом, а жіночий - високі, напр., пищати, верещати, але за певних комунікативних умов ці фізіологічні ознаки можуть взаємозамінюватися, ілюструючи емоційний стан чоловіка або жінки, зокрема обурення або захоплення, пригніченість або збудженість. Такі узагальнені гендерні уявлення можуть характеризувати мовця, зокрема чоловіка, що говорить бабським голосом, у певних комунікативних контекстах можна сприйняти як, наприклад, слабохарактерну, малодушну 
або підступну людину, натомість жінку, що говорить басом - як сильну й упевнену, в окремих випадках - як пригнічену або збентежену.

Важливу роль при цьому відіграє темп мовлення. Відповідно до ситуації мовлення або внаслідок власних артикуляційних здібностей або властивостей характеру, мовець може говорити, молоти, торохтіти, тараторити, цокотіти, розтягувати (слова), мимрити, що загалом створює певне уявлення про партнера 3 комунікації. Вагому роль при цьому відіграють гендерні стереотипи, що приписують, наприклад, жінці надмірну говірливість, нестриманість, а чоловікові помірність і зваженість у мовленні.

Однак, варто зважати й на міжкультурний аспект, що по-різному репрезентується в різних культурах, зокрема існують стійкі гендерні стереотипи, що приписують жінці або чоловікові певні моделі невербальної поведінки в певних комунікативних ситуаціях, наприклад, у деяких народів Австралії мовчання «закріплене» за вдовами, а не за вдівцями, а в мовленні чоловіків північноамериканських індіанців відсутні інтер'єктиви, що виражають і супроводжують страх, оскільки страх уважають притаманним лише жінкам, які мають на це відповідні вербальні маркери [7, с. 16, 18].

Отже, голосові модуляції насамперед залежать від прагматики мовлення, відводячи гендеру смислорозрізнювальну роль у сприйнятті й розумінні комунікативного дискурсу.

Від гендерних стереотипів переважно залежать і невербальні стилі поведінки чоловіка або жінки, зокрема у використанні кінетичних засобів - жестів, міміки, пози, рухів тіла й манери. Можна стверджувати, що перші чотири позиції зумовлені природними чинниками на генетичному рівні, наприклад, жести згоди або незгоди, міміка емоцій (посмішка, плач), поза ворожого ставлення або розгубленості тощо, й використовуються мовцем переважно на інтуїтивному рівні, чого не можна сказати відносно манер спілкування.

Під манерами розуміють «комплексні динамічні знакові форми, знання яких набуваються як у процесі накопичення суспільного досвіду, так і внаслідок спеціального навчання, що зумовлене необхідністю дотримуватися певних соціальних і культурних норм» [7, с. 18]. Ідеться про моделі поведінки, наприклад, під час прийому їжі, поведінки в гостях, етикетних манерах мовної поведінки тощо. Отже, тут також відображена певна етнічна специфіка гендеру, оскільки ці моделі поведінки різняться в лінгвокультурах й утворюють відповідні невербальні стилі поведінки чоловіка й жінки. 
Грунтуючись на теоретичних висновках фахівців із невербальної комунікації (С. Григор'єва, Н.Григор'єва, Г. Крейдлін, А. Піз), дослідники гендеру (І. Баженова, А. Кириліна, Е. Чувіліна) умовно розрізняють кінетичні засоби за статевою приналежністю, зважаючи на стереотипові уявлення невербальної поведінки чоловіка й жінки, зокрема до типових чоловічих жестів фахівці відносять такі, як чухати потилищю в стані подиву; потирати руки як ілюстрація позитивних очікувань; плювати в стані роздратованості й гніву; бити кулаком об стіл, крісло, трибуну або будь-яку опору, розлютившись або доводячи свою рацію тощо. Питомо жіночими вважають жести сплеснути руками, виражаючи подив; закривати обличчя руками, хустинкою, пальиями в стані засмути, плачу; ходити вперед-назад, схрестивщи руки перед грудьми в стані роздратування, страху; відчай ілюструє такий жест, як заламувати руки; сором - опустити очі, дивитися в підлогу тощо, зокрема вираження гніву чоловіки можуть супроводжувати жестами, пов'язаними 3 кулаком: показати кулак, погрожувати кулаком, стиснути кулаки. Для жінок ці жести не характерні, адже вони супроводжують гнів, приймаючи, наприклад, такі пози: ставити руки в боки, класти руку на стегно, поширеним є рух тупати ніжкою, чобітком тощо. Як тут не згадати старий анекдот про чоловіка-грузина й жінку-українку, коли він спробував поставити їй умови сімейного спілкування: «Якщо я прийду додому і моя кепка буде зсунутою вліво - ти маєш подати мені вечерю, не ставити зайвих питань і догоджсти мені весь вечір; коли вправо - маєм вести зі мною лагідну бесіду, веселити мене весь вечір, а коли назад - маєш мене швиденько нагодувати й сховатися у своїи кімнаті»; на що жінка відповіла: «Гаразд, я зрозуміла, тільки якщо ти прийдеш додому $i$ побачиш, що я зустрічаю тебе в позі «руки в боки», то мені все одно, на який бік у тебе зсунута кепка». Як бачимо, розуміння кінетичних маркерів у міжкультурній комунікації має суттєве значення для успішного спілкування.

Утім варто зважати й на те, що такий поділ припустимо сприймати лише умовно, оскільки він може нівелюватися соціальними й культурними чинниками, індивідуальністю кожної особистості, часо-просторовим фактором.

Отже, дослідження гендерних особливостей невербальної й вербальної комунікації сприяє визначенню універсальних ознак загальнолюдської взаємодії, а також виокремленню характеристик культурно маркованих, індивідуально специфічних. 
Перспективу цієї наукової розвідки становить більш детальне вивчення гендерного дискурсу в різних його проявах 3 метою виявлення специфіки комунікативних процесів між чоловіком i жінкою, пошуку ефективних моделей спілкування.

\section{Література}

1. Гингер Серж Женский мозг - мужской мозг / Серж Гингер // Выступление на XI конгрессе Европейской ассоциации психотерапии «Психотерапия - идентичность и противоречия» : [електронний ресурс] / Режим доступу: http://woman.health-ua.com/article/12.html

2. Кирилина А. В. Гендер: Лингвистические аспекты / А. В. Кирилина. - М. : Изд-во «Институт социологии РАН», 1999. - 180 с.

3. Кирилина А. В. Дослідження гендеру в лінгвістичних наукових дисциплінах / А. В. Кирилина // Гендерное образование в системе высшей школы : состояние и перспективы. Материалы международной научно-практической конференции. Иваново, 24-25 июня 2003 г. - Иваново, 2003.- С. 132-136.

4. Клещова О.Є. Мовлення чоловіків і жінок у соціолінгвістичному аспекті/ О. Є. Клещова // Лінгвістика : зб. наук. праць ЛНУ ім. Тараса Шевченка. - № 3 (24). Ч. 2. - Луганськ, 2011. -232 с.

5. Коноваленко И. В. Коммуникативные тактики русской речи в аспекте их гендерной специфики (на материале исследования колкости) / И. В. Коноваленко // Гендер : Язык. Культура. Коммуникация / Материалы III Международной конференции 27-28 ноября 2003 г. - М. : МГЛУ, 2003. - С. 62-63.

6. Крейдлин Г. Е. Мужчины и женщины в невербальной коммуникации : культурно-универсальные и культурно-специфичные особенности невербального коммуникативного поведения / Г. Е. Крейдлин // Гендер : Язык. Культура. Коммуникация / Материалы III Международной конференции 27-28 ноября 2003 г. М. : МГЛУ, 2003. - С. 67-68.

7. Крейдлин Г. Е. Просодика, семантика и прагматика невербального коммуникативного поведения: жесты, позы и знаковые телодвижения женщин и мужчин / Г. Е. Крейдлин // Гендер : Язык. Культура. Коммуникация : доклады II Международной конференции 22-23 ноября 2001 г. / Моск. гос. лингвистич. ун-т., Лаб. гендерных исслед. M., 2002.

8. Першай А. Гендерные аспекты речевого поведения / А. Першай // Журнал «Иной Взгляд» : Международный альманах гендерных исследований. Май 2000. - № 2. - Минск, 2000. - C. 11-12.

9. Путрова М. Интерпретация значения слова: гендерный контекст / М. Путрова // Материалы II Международной междисциплинарной научно-практической конференции «Женщина. Образование. Демократия» 1999 г. : [електронний ресурс]. - Режим доступу: http://envila.iatp.by.

10. Сакулина Е. Л. Современные стереотипы маскулинности и феминности у молодежи / Е. Л. Сакулина // Социокультурный анализ гендерных отношений / ред. Е. Ярской-Смирновой. - Саратов, 1998. - 208 с.

11. Сидорская И. «Женская» и «мужская» стратегии анализа проблем коммуникации / И. Сидорская // Материалы II Международной междисциплинарной научно-практической конференции «Женщина. Образование. Демократия» 1999 г. [електронний ресурс]. - Режим доступу : http://envila.iatp.by [10]. 
12. Сироткина Ю.Н. Гендерные различия в детской речи (о разных путях усвоения языка) / Ю. Н. Сироткина // Гендер : Язык. Культура. Коммуникация / Материалы III Международной конференции 27-28 ноября 2003 г. - М. : МГЛУ, 2003. - C. 99-100.

13. Снегова Т. И. О гендерной стереотипизации образа юриста / Т. И. Снегова // Гендер : Язык. Культура. Коммуникация / Материалы III Международной конференции 27-28 ноября 2003 г. - М. : МГЛУ, 2003. - С. 102-103.

14. Ставицька Леся Мова і стать / Леся Ставицька. HYPERLINK / [електронний pecypc]. - Режим доступу : http://krytyka. kiev.ua /articles/s9_6_2003.html

15. Стернин И. А. Проблема описания гендерного коммуникативного поведения / И. А. Стернин // Гендер : Язык. Культура. Коммуникация / Материалы III Международной конференции 27-28 ноября 2003 г. - М. : МГЛУ, 2003. - С. 106-107.

16. Українська система найменувань адресата мовлення : [колективна монографія] / М. С. Скаб, М. В. Скаб, Н. Д. Бабич та ін. - Чернівці : Рута, 2008. - 304 с.

17. Шевелева Л. В. Гендерный стереотип емоциональности в речевом поведении субъекта / Л. В. Шевелева // Гендер : Язык. Культура. Коммуникация / Материалы III Международной конференции 27-28 ноября 2003 г. - М. : МГЛУ, 2003. - С. 123-125.

Стаття надійшла до редакції 04.09.2012 p. 